\title{
Academic Dishonesty among Tertiary Institution Students: An Exploration of the Societal Influences Using SEM Analysis
}

\author{
Adesile M. Imran \\ Doctoral Student \\ Institute of Education, International Islamic University Malaysia \\ P O Box 10, Gombak 53100, Malaysia \\ Tel: 60-12-910-8901Ｅ-mail: adesileimraan@yahoo.com
}

Oseni R. Ayobami

Ph.D. Candidate, International Islamic University Malaysia, Malaysia E-mail: rahman.oseni@yahoo.com

Received: April 15, 2011

doi:10.5296/ije.v3i2.636
Accepted: October 16, 2011 Published: November 7, 2011

URL: http://dx.doi.org/10.5296/ije.v3i2.636

\begin{abstract}
This study examined the influence of societal factors on academic dishonest conducts of the Nigerian tertiary education students. A total of two hundred and thirty-one Nigerian students drawn from three of the public universities in Malaysia (IIUM, UPM, \& USM) were included in the study. An instrument tagged: “Academic Dishonesty Survey (ADS)” was used for data collection. Both the Principal Component Analysis method (PCA), reliability tests via (cronbach's alpha), and average variance extracted (AVE) were employed to generate adequate supports for convergent and discriminant validity of the constructs of the instrument. The result of the full-fledged structural equation modeling (SEM) indicated that societal factor had indirect effect on academic conducts of students through cognitive processes. Implications of the study were discussed and suggestions were advanced.
\end{abstract}

Keywords: Academic dishonesty, Societal factors, Higher education, PCA, AVE, SEM 


\section{Introduction}

Academic dishonesty has been taught of as serious concern among the stake-holders of higher education (Levy \& Rakovski, 2006). It is a phenomenon frequently described as widespread at tertiary institutions (Prenshaw, Straughan, \& Albers-Miller, 2001), and occurs at epidemic proportion (Hutton, 2002; McCabe, 1993; Niels, 1996). Studies abound on the prevalence of academic dishonesty at colleges and universities. Reports from multi-institutional studies showed that respondents between the range of 39\% and 70\% acknowledged involvement in academic dishonesty during their college years (Bowers, 1964; McCabe, 1992, 1993; Aluede, Omoregie \& Osa-Edoh, 2005; Pino \& Smith, 2003).

In the report of a thirty years follow up study on student's cheating, Wotring (2007) remarked that the population of students' cheaters increased from $63 \%$ to $70 \%$. He declared further that the cheaters of 1990s compared to those of 1960s have advanced in variety of cheating behaviors and cheated more often. A study by Diekhoff, LaBeff, Clark, Williams, Francis, and Haines (1996) also found a percentage increase in the level of academic integrity violation over a period of ten years $(1984-1994)$.

Similarly, some researchers (based on survey studies) reported that almost one-third of the six thousand students from thirty one colleges and universities had indulged in cheating (McCabe, 1999); more than 30\% plagiarized on all their papers (Bloomfield, 2005); and one hundred and seventeen fresh students used emails to exchange answers in an examination (Wilson, 1999). The aforesaid reports depict the dangerous dimensions that academic dishonesty has assumed on a global scene. The Nigerian educational institution is not an exception in this unholy academic practice.

Olatunbosun (2009) remarked that the last two decades of the Nigerian educational institution have witnessed an increase in the rate of examination malpractices. In tandem with Olatubosun, several news reports from the Nigerian daily newspapers had decried the rate of involvement of students, parents and teachers in the pervading examination imbroglio (Daily Independent, 2004; Nigerian Tribune, 2009; Vanguard, 2005; Weekend Pointer, 2005 [all cited in Olatunbosun, 2009]).

Nigerian scholars had dissipated lots of efforts towards unraveling circumstances of academic dishonesty in the country. Some of the issues examined include the historical account of examination malpractices in Nigeria (Olajuwon, 2006), forms of examination malpractices (Ijaiya, 2004; Olajuwon, 2006; Olasheinde, 1993), causes of examination misconduct (Alutu \& Aluede, 2006; Ivowi, 1997; Nwandiani, 2005; Olasheinde, 1993; Olatubosun, 2009), implications of examination malpractices (Ijaiya, 2004; Olatubosun, 2009), and ways of curbing examination malpractices (Olajuwon, 2006; Olasheinde, 2008; Olatubosun, 2009).

Other studies on academic dishonesty focused on characteristics of students who cheat (Whitley, 1998), methods of cheating (McCabe, 1993, 2001, McCabe \& Bowers, 1996), and ways of fostering academic honesty (Center for Academic Integrity, 1999; Ijaiya, 2004; McCabe, 2001, 2003; Olasheinde, 2008; Pamela, Justice, \& Weeks, 2009).

Despite the scholarly attentions this phenomenon has attracted, academic dishonesty still 
occurs at alarming rate in post-secondary schools (Aluede et al., 2006). The persistence of this problem could be because the existing literatures have consistently focused on one aspect of the issue (the school factors) and paid less attention to other crucial issues such as the societal factor itself. Most of the studies done so far have largely been limited to the roles of the school-based factors such as, deficiency in the school academic policy, unconcerned attitudes of the faculty members, school management attitudes, peer influences, and so on. Invariably, the influence of other crucial factors (those outside the school setting) was left unexamined.

Literature showed that individual actions could be shaped by larger forces which transcend internal, organizational, and institutional boundaries (Gallant Bertram, 2008). Students' behaviors, thoughts and actions are products of many factors (McCabe, 2001; Nadelson, 2007). Variables such as cognitive development and environmental situation play important role (Bandura cited in Nadelson, 2007). According to Odunayo and Olujuwon (2010), corrupt practices in the Nigerian society are deeply rooted in the negative values and attitudes propagated by members of the society. Although, it makes sense to fashion a link between the prevalent social orders in the society and the moral conducts of the grown-up youth. The empirical evidences to substantiate this claim are relatively scarce or non-existent in the existing literatures.

The purpose of this study therefore, was to investigate the influence of environmental factors (from two dimensional levels - the school and societal effects) on dishonest tendency of higher institution students. Specifically, the study intended to determine whether societal factors have direct and indirect effects on the students' moral conducts.

\section{Theoretical Framework}

There are several psychological theories on how educators could make sense of rationales for students' moral conducts (Chickering, Dalton \& Stamm, 2006). Some of these theories include Social Cognitive Theory of Moral Thought and Action (Bandura, 1991a), Deterrence Theory (Gibbs, 1975), Theory of Crime (Gottfredson \& Hirschi, 1990), Big Five Model of Personality (De Read \& Perugini, 2002; McCrae \& Costa, 1985), Theory of Planned Behavior (Ajzen, 1991 \& 2002), and so on. In all this, Albert Bandura's Theory has received a more considerable attention (Nadelson, 2007). It has been shown very useful for analyzing students' moral development and thought making process. Thus, the present study is premised on the framework of the theory. The figure 1 below presents the model.

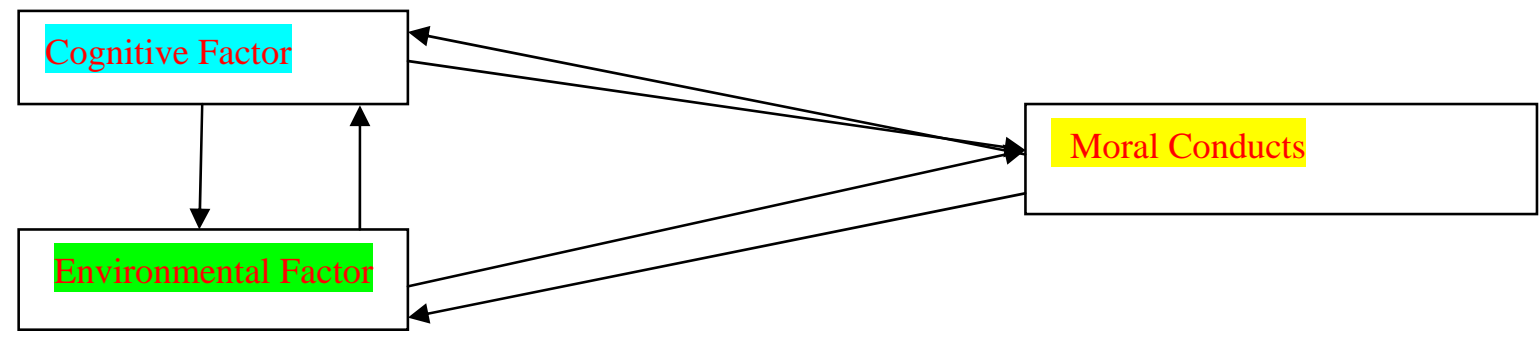

Figure 1. The Model of Social Cognitive Theory of Moral Thought and Action (Albert Bandura, 1991a)

Albert Bandura's Social Cognitive Theory of Moral Thought and Action sheds light on many 
interactions that shape person's thought, environment, and behavior. Bandura analyzed complex concepts relating to student moral action in a three-part bi-directional model. According to him, moral behavior (e.g., honesty/dishonesty) is shaped by cognitive and environmental factors. Cognitive aspects according to (Bandura, 1991b), include intellectual and moral developmental levels, thought processes, beliefs, reaction to situation and social norms.

The environmental variables in this case include commitment to social norms, codes of conduct, and modeling by others. By social norms, Bandura (1991b) implied the perceived acceptable behaviors. These norms influence what people feel they should do or not doing. Codes of conduct also affect behavior by providing a better understanding of social norms and expectations. Finally, modeling provides people with visual clues regarding what is - or is not - acceptable behavior. Bandura's research, therefore, suggests that students' behaviors could be positively impacted through a formidable code of conducts, creating a friendly learning environment, and working to develop desirable social norms that are congruence with appropriate character development.

Although Bandura's Theory focused on interactions among variables that shape individual's ethical conducts, most studies in this direction have reduced these variables to the school-based factors. Empirical data are lacking regarding the connection between societal-induced factors and academic dishonest conducts in schools. Besides, there are fewer applications of Bandura's Theory in Non-Western educational settings. The current study hopes to fill parts of this vacuum by showing a more informed relationship among the underlying variables of academic dishonesty. The figure two below presents the modified framework of the Bandura's Theory.

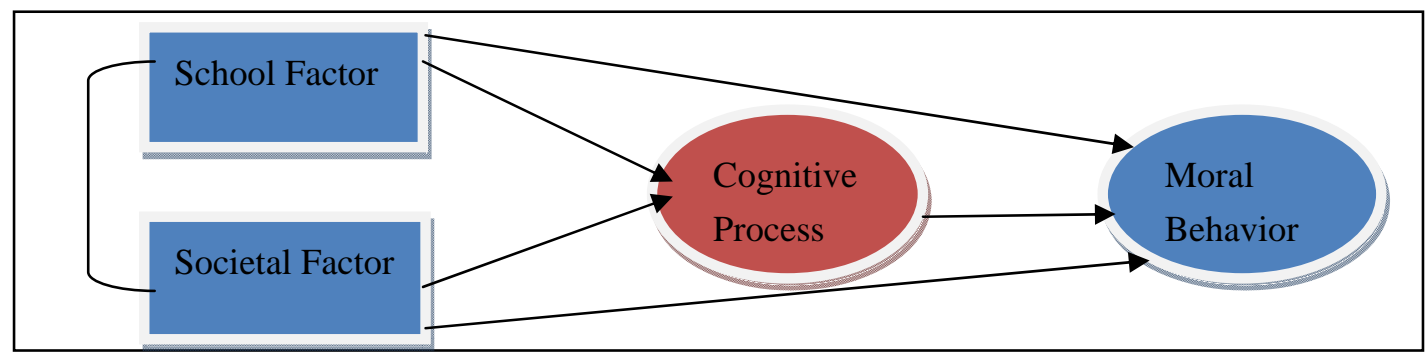

Figure 2. The Modified Framework

\section{Research Hypotheses}

The thrust of this study is guided by the following hypotheses:

1. Academic dishonesty is a multi-dimensional construct.

2. Academic dishonesty is directly predicted by both school and non-school based environmental factors.

3. Dishonest behavior is indirectly predicted by societal factors through cognitive process.

\section{Methodology}

\subsection{Participants}

This study consisted of 231 respondents chosen from the population of the Nigerian students at the International Islamic University Malaysia and two other public universities in Malaysia 
(UPM and USM). The selected respondents were registered students during second semester 2010/2011 academic session, at each of the respective institutions. The respondents' demographic analysis showed that $75 \%$ were postgraduate and the remaining $25 \%$ were undergraduates. Also, $70 \%$ of the respondents were male while $30 \%$ were females. Their ages ranged from 22yrs to 58yrs, with mean $=33 y$ rs. Majority of the respondents $(65 \%)$ were married while the remaining $35 \%$ were single.

\subsection{Instrument}

This study used a modified survey instrument tagged: “Academic Dishonesty Survey - (ADS)” for data collection. The constructs of this instrument were measured using a five point Likert-type scale ranging from strongly disagree $(1$ point) to strongly agree ( 5 point). The scales have a minimum of seven items (for environment construct) and a maximum of fifteen for cognitive construct. The third scale (moral behavior) has only eleven items. The total valid and reliable items that make a final instrument were thirty-three. Detailed about the validation and reliability procedures are discussed in the subsequent paragraphs.

\subsection{Reliability and validation processes for the instrument}

Construct validity and reliability are issues of great concern especially in survey research (Creswell, 2008). This study used questionnaire as the main tool of data collection. Three major procedures were followed to establish the reliability and validity of the ADS. First, a reliability test was conducted for all the items that made the three constructs. The Cronbach's alpha reliability coefficient identified the items for all the constructs as internally consistent, though, after removing twenty items on the basis that their Cronbach's alpha coefficients were low, fell below the threshold (.5). The second procedure involved the use of the exploratory principal component analysis (PCA) tool to determine the number of underlying factors/components that the items represent. This was done with due attention to the underlying assumptions of factor analysis. At the end of the exercise, the three constructs (the environmental, cognitive and moral conduct) yielded six factors altogether, two for each construct. The environmental construct had seven items (four and three items respectively for the two factors); cognitive construct had eleven items (six and five respectively for the two factors); and lastly, the moral construct consisted of fifteen items (nine and six respectively for the two factors). This exercise provided strong evidence in supporting the constructs as multi-dimensional (evidence for the first research hypothesis).

Thereafter, the data were further subjected to another round of statistical analyses - the calculation of reliability estimate for each of the sub-scales; and the calculation of shared variance (SV) and average variance-extracted (AVE) for each construct. This procedure provided additional supports for evidence of convergent and discriminant validity of the constructs (Fornell \& Larcker, 1981; Byrne, 2010). This exercise yielded desirable results for all the constructs. The Cronbach's alpha obtained for each of the sub-scales was .90 and above. The average variance extracted (AVE) values for the three constructs were higher than the threshold point ".5” (adequate support for convergent validity), and the shared variances (SV) were smaller than the calculated AVE (additional evidence for descriminant validity). Detailed 
of the cronbach's alpha, factor loadings, shared variance and total variance-extracted, are presented in the table 1 below.

Table 1. PCA Factor Loadings and Validating Estimates for the ADS Measure

\begin{tabular}{|c|c|c|c|c|c|}
\hline Constructs & Indicators & Factor Loading & C’alpha & Shared Variance & Variance-Extracted \\
\hline School- & HP1 & .96 & .93 & & .79 \\
\hline \multirow[t]{3}{*}{ Factor } & HP2 & .90 & & & \\
\hline & HP3 & .85 & & & \\
\hline & HP4 & .84 & & .43 & \\
\hline Societal- & SO1 & .94 & .90 & & .88 \\
\hline \multirow[t]{2}{*}{ Factor } & $\mathrm{SO} 2$ & .87 & & & \\
\hline & S03 & .83 & & & \\
\hline People’s & PP1 & .95 & .91 & & .66 \\
\hline \multirow[t]{4}{*}{ Expectation } & PP2 & .82 & & & \\
\hline & PP3 & .81 & & & \\
\hline & PP4 & .77 & & & \\
\hline & PP5 & .70 & & & \\
\hline Self- & SEC1 & .77 & & .30 & \\
\hline \multirow[t]{5}{*}{ Conscience } & SEC2 & .77 & .95 & & .53 \\
\hline & SEC3 & .75 & & & \\
\hline & SEC4 & .74 & & & \\
\hline & SEC5 & .67 & & & \\
\hline & SEC6 & .65 & & & \\
\hline \multirow[t]{9}{*}{ Cheating } & CHT1 & .94 & .96 & & .70 \\
\hline & СНT2 & .93 & & & \\
\hline & СНТЗ & .91 & & & \\
\hline & CHT4 & .90 & & & \\
\hline & CHT5 & .89 & & & \\
\hline & CHT6 & .89 & & & \\
\hline & CHT7 & .76 & & & \\
\hline & СНT8 & .67 & & & \\
\hline & СНT9 & .55 & & .52 & \\
\hline \multirow[t]{6}{*}{ Plagiarism } & PLG1 & .92 & .92 & & .59 \\
\hline & PLG2 & .90 & & & \\
\hline & PLG3 & .78 & & & \\
\hline & PLG4 & .76 & & & \\
\hline & PLG5 & .72 & & & \\
\hline & PLG6 & .52 & & & \\
\hline
\end{tabular}

Upon the evidence of valid and reliable constructs of the ADS, the hypothesized model for the study was tested using the full-fledged structural equation analyses. This exercise witnessed the specification and respecification of structural equation models. Also, a summated score (Byrne, 2010; Hair, Black, Babin, \& Anderson, 2010) was computed for the factorial dimensions of each of the three main constructs. 


\section{Macrothink}

The first analysis revealed poor fit indices for the model: the norm chi-square (cmin/df) was estimated to be .999; the Comparative Fit Index (CFI) 1.000; and the Root Mean Squared Error of Approximation (RMSEA) was 000. Apart from the fit indices that appeared too unfit, the targeted effect between societal order (SO) and moral conduct (MOC) was negative (-.20) and not significant at an alpha level of .05. Thus, the model required a respecification to achieve a desirable fitness (Byrne, 2010; Kline, 2005). The detailed of the model and its causal effects among the constructs are displayed below in the figure 3 and table 2 respectively:
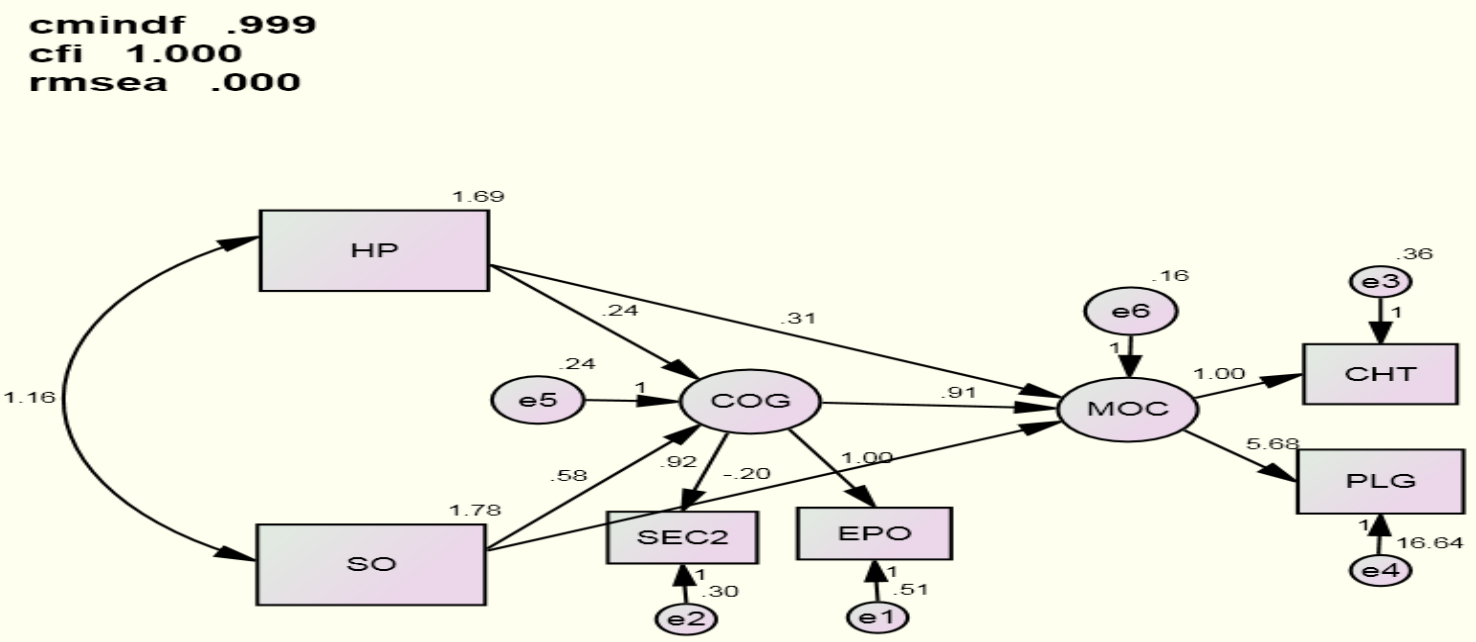

Figure 3. The First Academic Dishonesty Model

Table 2. The unstandardized causal effects for the first model

\begin{tabular}{|l|l|l|l|l|l|}
\hline & & \multicolumn{2}{|c|}{ Causal Effects } & & \\
\hline Outcome & Determinant & Direct & Indirect & r & Total \\
\hline COG & HP & .24 & - & - & .24 \\
\hline & SO & .58 & - & - & .58 \\
\hline MOC & COG & .91 & - & - & .91 \\
\hline & HP & .31 & .22 & - & .53 \\
\hline & SO & .20 & .53 & - & .73 \\
\hline HP $<>$ & SO & - & - & .67 & .67 \\
\hline
\end{tabular}

$<>=$ r (correlation)

\subsubsection{The Revised Model}

The revised model was run with a constraint imposed on the path effect between societal order and moral conduct. This was done because the initial model indicated that the two relationships were insignificant and bore negative effects for each other. This revised exercise generated a desirable result. The statistical significance and practical importance was achieved. The followings are the fit indices obtained for the constrained model: the CFI became more robust $(.997)$, the Norm Chi-square $(\mathrm{Cmin} / \mathrm{df})=1.508$ and the Root Mean Squared Error of Approximation (RMSEA) $=0.047$. 

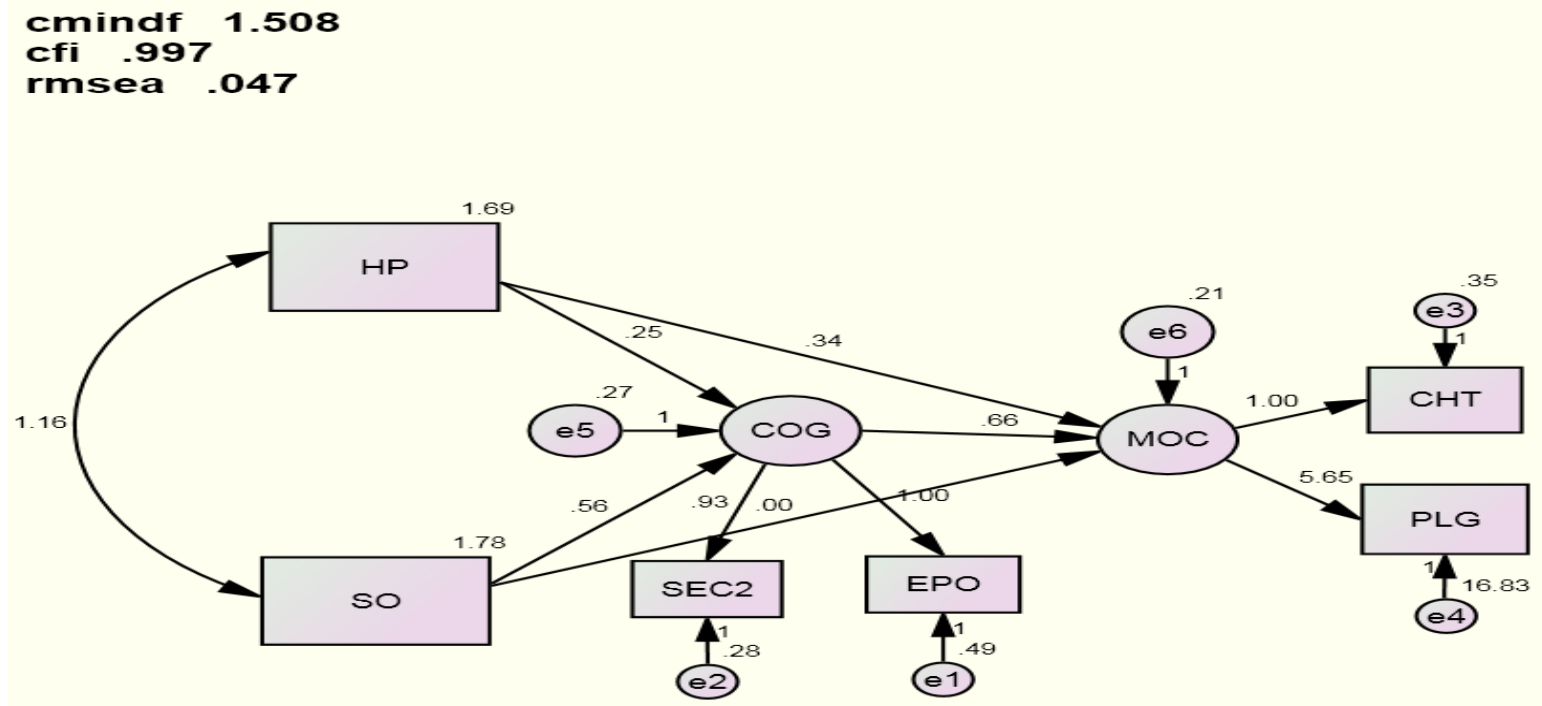

Figure 4. The Revised Model with adequate Fit Statistics

Table 3. The unstandardized causal effects for the revised model

\begin{tabular}{lccccc}
\hline Outcome & Determinant & Direct & Indirect & $\mathrm{r}$ & Total \\
\hline COG & HP & .25 & - & - & .25 \\
\multirow{2}{*}{ MOC } & SO & .56 & - & - & .56 \\
& SEC & .66 & - & - & .66 \\
& HP & .34 & .17 & - & .51 \\
HP & SO & constraint & .36 & - & .36 \\
\hline$<>=$ r (correlation) & SO & - & - & .67 & .67 \\
\hline
\end{tabular}

Besides, all the parameter estimates were practically reasonable, no offending estimates. The model estimate output also revealed that all the loadings were statistically significant (.5 and above). Further analysis of the model estimate showed that the hypothesized relationships among the constructs were statistically significant and practically important, except the constrained one. The Critical Ratio (CR) values for each of the relationships was greater than 1.96 (absolute value) at alpha level $(\mathrm{p}<.05)$. Thus, the evidence of direct and indirect relationships among the constructs was established. This result showed that the school policy (HP) exerts direct effect on moral conduct (0.34), and indirect effect through cognitive process (0.53). For the societal order (SO), the estimated indirect effect on moral conduct (MOC) through cognitive process (COG) was .36. Whereas, its direct effect was constrained. This may be because the sample size was not large enough. All the effect estimates were statistically significant and logically reasonable. They also reached acceptable standard for evidence of direct and indirect effects (.2 and .08 respectively). Thus, it is profoundly established that this study found cognitive process (COG) as a good mediator between the Environmental factors (the school and societal order) and the student's moral conducts. The figure 3 below shows detailed of the revised model with adequate fit statistics, and table 2 
and 3 present the causal relationships among constructs for the first and revised models.

\section{Discussion/Implication}

The ultimate goal of this study was to generate empirical explanation for interconnections among variables that shape academic dishonesty in tertiary institutions. The findings from this research (figure 4 and table 3 ) showed that the school factors such as academic honesty policy, faculty and school management attitudes, and so forth have both direct and indirect effects on the moral conduct of students. This finding agrees with the previous studies where unconcerned attitudes of faculty members and ineffective academic honesty policies were reported as reasons why many students participated in academic dishonesty (McCabe, Trevino, \& Butterfield, 1999; McCabe, 2001, 2005; Scanlan, 2006; Simon, Carr, McCullogh, Morgan, Oleson, \& Ressel, 2004; Prenshaw et al., 2001). For instance, in a large scale study on the effectiveness of honor code practices, majority of the respondents felt disturbed about the failure of their institutions and faculty to address cheating problem properly (McCabe et al., 1999). The need for institutionalizing a sound and effective academic integrity policy within the school system is, therefore, imperative so as to address the environmental causes of academic dishonesty that are due to the school practices. Such effort should gear towards effective and thorough implementation of academic integrity policies. It should be bore in mind that it is not enough to formulate standard policies, translating the policy into a meaningful action via judicious implementation is equally more important.

Also, societal factor (social order, social practices, norms and value orientations) was found to have an indirect effect on moral conduct through cognitive process. This suggests that societal practices affect the way students think and consequently determine their actions or conducts. This finding is not surprising, though, with many far reaching implications. It is commonsensical to anticipate such a relationship even though there is little empirical research in this direction. This finding corroborates some previous reports that students' conducts are shaped by many factors which transcend internal and organizational settings (Nadelson, 2007; McCabe, 2001, 2002).

Furthermore, some studies have reported a significant relationship between the level of college cheating and a country's corruption index (Magnus, Polterovich, Danilov, \& Savvateev, 2002). The possibility that students thought processes would be shaped by societal practices cannot be queried too far. Some researchers have noted that how students think and what affects their decisions to act dishonestly, are all important factors which when understood, the incidence of academic dishonesty could be curtailed (McCabe, Feghali \& Abdalah, 2008). The present and the previous findings are pointers to the fact that societal factor is a strong force to reckon with in tackling the dishonesty practices among tertiary education students. This is true because, the students and the schools are parts of the larger forces that constitute a society. The students are born in a society, grow and develop therein, and imbibe its (society) norms and values (i.e., either consciously or unconsciously). It follows that the students' practices and conducts at schools, are prone to be shaped and influenced by the cultures and values of the society wherein they grew and developed.

The above fact suggests that a society where negative values such as corruption and moral 
decadences are order of the day, a fast majority of its grown-up youth would find pleasure in venturing into unholy academic conducts at schools; and would rarely see any need to respect and comply with laid down rules for academic excellence. Thus, societal influence needs to be recognized and treated with great concern in any intervention strategy designed to deal with academic dishonesty in tertiary institutions. According to Hallack and Poisson (2007), corrupt practices in education limit the scope of educational attainments, and make the overall goals of education unfeasible. Corruption tends to encroach on the resources available for education, hinders access to it, especially, for underprivileged people in the society. Consequently, the tempo of social inequalities worsens and educational institutions are marred with eroded/fallen standards.

\section{Implication and Recommendation}

The findings of this study have several implications for the educators, policy makers, and above all, the political office-holders of any given country. The higher education administrators must consider these findings good news because part of it suggests that not only the context created within academic institution but also the societal value system have a powerful impact on student academic conducts. This finding is thus, an eye-opener towards a direction of interventions that are likely to work. As submitted by McCabe and Trevino (1993), one important question regarding academic dishonesty is how an institution could create environment where academic dishonesty is socially unacceptable, that is, where students disapprove of cheating and where new students find that cheating on campus is the exception rather than the rule. One approach to academic integrity in colleges and universities that has yielded success at many institutions is the establishment of honor code. Previous studies have shown that cheating is significantly lower at honor-code institutions (Bowers, 1964; McCabe and Trevino, 1993). Honor codes are characterized by an honor pledge, peer reportage, unproctored examinations, and a peer-run judiciary or honor council. Nevertheless, the findings of this study suggest that strong commitment to implement academic integrity policies could be a good antidote to the problem of academic dishonesty.

Another important implication of this study for the teeming population of the Nigerian society is the need to be weary of the effect of societal practices on education. This study found negative value system in the society to bear some substantial effects for student's moral conducts. Some students simply see dishonest practices as necessary means to attain success because that is what they see, experience and imbibe from the society. Thus, the political leaders at various governmental levels, the public opinion analysts, the civil society organizations, members of the press, and all other influential members of the society are called upon to channel a course of action through which the present collapsed value system of the nation can be addressed and healthy values are promoted. This is necessary to save the future generation from bequeathing onto them, culture of shame and deceit.

Besides, as part of the required approach to tackle the problem of value disorientation, a national conference may be convened where all stake-holders in the country's affairs could rub minds and generate practical ideas for regaining and resuscitating the lost positive value systems and practices. If this suggestion is executed in good faith and with sincerity of 
purpose, it is most likely that fruitful results would be attained.

Another practical approach to tackle the degenerating value system in the country is to strengthen and empower educational policies to be active and functional in order to fulfill its role of inculcating positive values to the learners. The present practices in many parts of the nation's institutions, where value-inclined subjects such as religious studies, philosophy, ethics, literature, etcetera are closed down to give preferences to the market-oriented courses are regrettable. Efforts should be geared toward offering and motivating students to go into this area of value-oriented knowledge. Also, the policy makers can assist the situation by designing compulsory ethical/value based courses for all students at tertiary institutions irrespective of their field of specializations. It is note-worthy that some institutions are already practicing some things similar to this suggestion. However, this needs to be extended to institutions all over the country.

\section{Conclusion}

This study found both school and societal factors contributing to the problem of academic dishonesty in the Nigerian tertiary institutions. Albeit, the effect of the societal factor is indirect, it is no less important. Therefore, all stake-holders of higher education in the country are called upon to pay concerted attention to some of the suggestions discussed in this study (under implication and recommendation - Section 6), so as to find a lasting solution to the protracted problem of academic dishonesty in the nation's institutions.

\section{Limitation}

The present study is a small scale with limited number of sample size and participating institutions. The participants are basically Nigerian students in Diaspora. The context of teaching/learning in Malaysia is somehow different from what was available back home - in Nigeria. Hence, the possibility that the respondents' views and responses were shaped by differences in the context of learning, could not be rule out completely. Henceforth, the extent that the findings could be generalized is also curtailed. Consequently, the future studies would do well to consider a bigger sample size draws from locally based institutions in the home country. Besides, the indirect effect of societal factors on students' academic conducts (through cognitive processes) deserves further exploration, probably, through structural invariance analyses on different groups. This would help to show how well the model of academic dishonesty of this study is adequate and consistent across different sub-groups within the population, and thus, enhance its generalizable impact.

\section{Acknowledgement}

We wish to express profound gratitude to Prof Dr Mohamad Sahari Nordin (Dean, IIUM's Research Management Center) - for all his efforts and supports in the process of this research. His untiring guidance and tutoring provides the needed logistics for the completion of this study.

\section{References}


Ajzen, I. (1991). The theory of planned behavior. Organizational Behavior and Human Decision Processes, 50, 179-211. [Online] Available: people.umass.edu/psyc661/pdf/tpb.obhdp.pdf

Aluede, O., Omoregie, E.O., \& Osa-Edoh, G. I. (2006). Academic dishonesty as a contemporary problem in higher education: How academic advisors can help. Reading Improvement, 43(2), 97-106.

Alutu, A. N. G., \& Aluede, O. (2006). Secondary school students' perception of examination-malpractices and examination ethics. Journal of Human Ecology, 20(4). [Online] Available: www.krepublishers.com/...Journals/...20...20-4...20-4...JHE-20-4-29...

Bandura, A. (1991a). Social cognitive theory of moral thought and action. In S. Nadelson (20 -07), Academic misconduct by university students: Faculty perceptions and responses. Plagiary: Cross-Disciplinary Studies in Plagiarism, Fabrication, and Falsification, 2(2), 1-10. [Online] Available: quod.lib.umich.edu/cgi/p/pod/dod-idx?c=plag;idno=5240451...

Bandura, A. (1991b). Social cognitive theory of moral thought and action. In S. Nadelson (2007), Academic misconduct by university students: Faculty perceptions and responses. Plagiary: Cross-Disciplinary Studies in Plagiarism, Fabrication, and Falsification, 2(2), 1-10. [Online] Available: quod.lib.umich.edu/cgi/p/pod/dod-idx?c=plag;idno=5240451...

Bertram Gallant, T. (2008). Academic integrity in the twenty-first century: A teaching and learning imperative. ASHE Higher Education Report, 33(5), 1-143. San Francisco: Jossey-Bass.

Bloomfield, L. (2005). Discussions of plagiarism and academic misconduct. In: J. P. Boehm, M. Justice, and S. Weeks (2009): "Promoting academic integrity in higher education", Community College [Online] Enterprise. Available: www.schoolcraft.edu/pdfs/cce/15.1.45-61.pd

Bowers, W. J. (1964). Student dishonesty and its control in college. New York: Bureau of Applied Social Research, Columbia University.

Byrne, M. B. (2010). Structural equation modeling with Amos: Basic concepts, application, and programming ( $2^{\text {nd }}$ ed.). London, Routledge.

Chickering, A., Dalton, J., \& Stamm, L. (2006). Encouraging authenticity and spirituality in higher education. Jossey-Bass.

Creswell, J. W. (2008). Educational research: Planning, conducting, and evaluating quantitative and qualitative research (3rd ed.). Upper Saddle Creek, NJ: Pearson Education.

Daily Independent. (2004). Principal arrested for impersonation at exam hall. In J. B. Olatunb-osun (2009), Examination malpractice in secondary schools in Nigeria: What sustains it? European Journal of Educational Studies, 1(3). [Online] Available: ozelacademmy.com/EJESV1N3_1.pdf

de Raad, B., \& Perugini, M. (2002). Big Five factor assessment: Introduction. In: B. de Read 
\& M. Perugini (Eds.), Big Five assessment (pp. 1-26). Groningen: Hofgrebe \& Huber.

Diekhoff, G. M., LaBeff, E. E., Clark, R. E., Williams, L. E., Francis, B., \& Haines, V. J. (1996). College cheating: Ten years later. Research in Higher Education, 37(4), 487-501. http://dx.doi.org/10.1007/BF01730111

Gibbs, J. P. (1975). Crime, punishment, and deterrence. Amsterdam: Elsevier.

Gottfredson, M. R., \& Hirschi, T. (1990). A general theory of crime. Stanford, CA: Standford University Press.

Hair, J. F., Black, W. C., Babin, B. J., \& Anderson, R. E. (2010). Multivariate data analysis (7 ${ }^{\text {th }}$ ed.). Pearson Prentice Hall.

Hallack, J., \& Poisson, M. (2007). Corrupt Schools, Corrupt Universities: What can be done. Paris: International Institute for Educational Planning.

Hutton, A. P. (2002). Understanding student cheating and what educators can do about it. College Teaching, 54(1).

Ijaiya, N. Y. S. (2004). Agents of examination malpractice in Nigerian public examinations: The strongest links. Nigerian Journal of Educational Research and Evaluation, 5 (1). [Online] Available: www.unilorin.edu.ng/publications/nysijaiya/...

Ivowi, U. M. O. (1997). Examination malpractices: Profile, causes, warning signs, case studies, prevention and detection strategies. In I. Onyechere, Promoting Examination Ethics: The challenges of a collective responsibility. Lagos: Potomac Books.

Levy, E. S., \& Rakovski, C. C. (2006). Academic dishonesty: A zero tolerance professor and student registration choices. Research in Higher Education, 47(6), 735-755. http://dx.doi.org/10.1007/s11162-006-9013-8

Magnus, J. R., Polterovich, V. M., Danilov, D. L., \& Savvateev, A. V. (2002). Tolerance of cheating: An analysis across countries. The Journal of Economic Education, 33(2), 125-136.

McCabe, D. L. (1992). The influence of situational ethics on cheating among college students. Sociological Inquiry, 62, 365-374.. http://dx. doi.org/10.1111/j.1475-682X.1992.tb00287.x

McCabe, D. L. (1993). Faculty responses to academic dishonesty: The influence of student honor codes. Research in Higher Education, 34, 367-658.

McCabe, D. L. (1999). Academic dishonesty among high school students. Adolescence, 34, 681- 687.

McCabe, D. L. (2001). Cheating: Why students do it and how we can help them stop. American Educator Winter, 38-43.

McCabe, D. L., \& Trevino, L. K. (1993). Academic dishonesty: Honor codes and other contextual influences. Journal of Higher Education, 64, 520-538.

McCabe, D. L., Fighali, T., \& Abdallah, H. (2008). Academic dishonesty in the Middle East: 
Individual and contextual factors. Research in Higher Education, 49, 451-467. http://dx.doi.org/10.1007/s11162-008-9092-9

McCabe, D. L., Trevino, L. K., \& Butterfield, K. D. (1999). Academic integrity in honor code and non-honor code environments. The Journal of Higher Education, 70(2), 211-234

McCrae, R. R., \& Costa, P. T. (1985). Updating Norman’s adequate taxonomy: Intelligence and personality dimensions in natural language and in questionnaires. Journal of personality and Social Psychology, 49, 710-721.

Nadelson, S. (2007). Academic misconduct by university students: Faculty perceptions and-responses. Plagiary: Cross-Disciplinary Studies in Plagiarism, Fabrication, and Falsification, 2(2), 1-10. [Online] Available: quod.lib.umich.edu/cgi/p/pod/dod-idx?c=plag;idno=5240451...

Niels, G. R. (1996). Is honor code a solution to the cheating epidemic? In: J. P. Prenshaw et al. (2001), "University academic dishonesty policy and student perceptions of cheating: an exploratory content analysis across fourteen universities.” [Online] Available: www.sbaer.uca.edu/research/acme/ 2001/45.pdf

Nigerian Tribune. (2009). Students and exam malpractices, Lagos. In J. B. Olatunbosun (2009), Examination malpractice in secondary schools in Nigeria: What sustains it? European Journal of Educational Studies, 1(3). [Online] Available: ozelacademmy.com/EJESV1N3_1.pdf

Nwadiani, M. (2005). “Curbing examination malpractice in the Nigerian educational system.” A lead paper presented at the First Annual Conference of the Faculty of Education, Ambrose Alli University, Ekpoma, November, 10-12.

Odunayo, W., \& Olujuwon, T. (2010). Corrupt practices and educational values attainment in Nigeria society. European Journal of Social Sciences, 16(1), 64-74.

Olajuwon, O.T. (2006). Transforming the Nigerian educational system. [Online] Available: www.transformedu.org/LinkClick.aspx?fileticket=M...71...

Olasehinde, W. O. (2008). Lecturer and student sensitivity to academic dishonesty intervention approaches in the University of Ilorin, Nigeria. Education Research Review, 3(11), 324-333. [Online] Available: http://www.academicjournals.org/ERR

Olasheinde, F.A.O. (1993). Cheating in examinations in the University of Ilorin, styles causes and remedies. Nigeria Journal of Educational Foundations, 4 a.

Olatunbosun, J. B. (2009). Examination malpractice in secondary schools in Nigeria: What sustains it? European Journal of Educational Studies, 1(3). [Online] Available: ozelacademy.com/EJESV1N3_1.pdf

Pamela, J. B., Justice, M., \& Weeks, S. (2009). Promoting academic integrity in higher education. Community College Enterprise.

Pino, N. W., \& Smith, W. L. (2003, December). College students and academic dishonesty. College Student Journal, 37 (4). 
Prenshaw, J. P., Straughan, D. R., \& Albers-Miller, D. N. (2001). University academic dishonesty policy and student perceptions of cheating: An exploratory content analysis across fourteen universities. [Online] Available: www.sbaer.uca.edu/research/acme/ 2001/45.pdf

Scanlan, C. L. (2006). Strategies to promote a climate of academic integrity and minimize student cheating and plagiarism. Journal of Allied Health.

Simon, A. C., Carr, R. J., McCullogh, M. S., Morgan, J. S., Oleson, T., \& Ressel, M. (2004). Gender, student perceptions, institutional commitments and academic dishonesty: who reports in academic dishonesty cases? Assessment and Evaluation in Higher Education, 29(1). http://dx.doi.org/04/010075-16

Vanguard. (2005). "Rising exams malpractices” Vanguard Comment. In J. B. Olatunbosun (2009), Examination malpractice in secondary schools in Nigeria: What sustains it? European Journal of Educational Studies, 1(3). [Online] Available: ozelacademmy.com/EJESV1N3_1.pdf

Weekend Pointer. (2005). "Father writes GCE exam for son.” In J. B. Olatunbosun (2009), Examination malpractice in secondary schools in Nigeria: What sustains it? European Journal of Educational Studies, 1(3). [Online] Available: ozelacademmy.com/EJESV1N3_1.pdf

Wilson, R. (1999). Colleges urged to better define academic integrity and to stress its importance . Chronicle of Higher Education, 46(8), A18.

Wotring, E. K. (2007). Cheating in the community college: Generational differences among students and implications for faculty. Inquiry, 12(1), 5-13.

\section{Copyright Disclaimer}

Copyright reserved by the author(s).

This article is an open-access article distributed under the terms and conditions of the Creative Commons Attribution license (http://creativecommons.org/licenses/by/3.0/). 